\title{
APLIKASI OBAT HERBAL DAN MANAJEMEN KESEHATAN IKAN BAGI PETANI DI DESA PASIE PINANG KECAMATAN MEUREUBO KABUPATEN ACEH BARAT
}

\section{APPLICATION OF HERBAL MEDICINES AND FISH HEALTH MANAGEMENT FOR FARMERS IN PASIE PINANG VILLAGE, KECAMATAN MEUREUBO, WEST ACEH DISTRICT}

\author{
Rinawati $^{1^{*}}$, Zulfadhli², Radhi Fadhillah ${ }^{2}$ \\ ${ }^{1}$ Program Studi Kesehatan Masyarakat, Fakultas Kesehatan Masyarakat, Universitas Teuku Umar \\ ${ }^{2}$ Program Studi Akuakultur, Fakultas Perikanan dan IImu Kelautan, Universitas Teuku Umar \\ “Korespondensi : rinawati@utu.ac.id
}

\begin{abstract}
ABSTRAK
Infeksi penyakit pada usaha budidaya ikan menyebabkan penurunan hasil produksi dan gagal panen. Disisi lain penurunan produksi dan gagal panen juga dikarenakan pengetahuan dan ketrampilan petani dalam pencegahan dan pengobatan minim. Pengobatan menggunakan obat kimia terus menerus menyebabkan jamur/bakteri resisten sehingga susah dibasmi. Solusi yang ditawarkan untuk menyelesaikan masalah mitra adalah dengan memberikan sosialisasi manajemen kesehatan ikan dan penggunaan obat alami. Tahapan pelaksanaan meliputi: penyusunan program, pelaksanaan program, monitoring dan evaluasi, lokakarya dan pelaporan. Hasil pengabdian diperoleh bahwa petani ikan mendapatkan peningkatan pengetahuan tentang manajemen kesehatan ikan dan penggunaan obat herbal.
\end{abstract}

Kata kunci: obat, alami, manajemen, kesehatan, ikan

\section{ABSTRACT}

Disease infection in fish farming causes a decrease in production yields and crop failure. On the other hand, the decline in production and crop failure is also due to the lack of knowledge and skills of farmers in prevention and treatment. Treatment using chemical drugs continuously causes resistant fungi / bacteria so that it is difficult to eradicate. The solution offered to solve partner problems is to provide information on fish health management and the use of natural medicine. Implementation stages include: program preparation, program implementation, monitoring and evaluation, workshops and reporting. The results of this service show that fish farmers get increased knowledge about fish health management and the use of herbal medicine.

Keywords: medicine, natural, management, health, fish

\section{PENDAHULUAN}

Desa Pasie Pinang merupakan salah satu desa di Kecamatan Meureubo Kabupaten Aceh Barat Provinsi Aceh. Desa ini berada di wilayah pesisir, sehingga sebagian besar masyarakat setempat berprofesi sebagai nelayan dan petani. Selain itu masyarakat juga menekuni usaha budidaya ikan, ini terlihat dari adanya kelompok petani ikan dan di wilayah desa ini terdapat banyak kolam dan keramba ikan. Potensi usaha budidaya ikan wilayah ini sangat baik karena sumber air yakni sungai besar meureubo, serta pemasaran yang strategis karena dekat dengan pusat kota meulaboh.

Kelompok petani ikan di Desa Pasie Pinang sudah ada sejak tahun 2000 yang bergerak dibidang usaha budidaya ikan. Aktivitas budidaya ikan sempat berhenti tahun 2004-2007 akibat bencana tsunami yang menghancurkan semua kolam dan keramba ikan. Seiring waktu berjalan, pada tahun 2008 kelompok petani ikan mulai bangkit dan merintis kembali usaha budidaya ikan. Komoditi ikan yang paling banyak 
dibudidayakan adalah ikan lele dan ikan nila, namun ada beberapa petani juga yang membudidaya ikan mas dan ikan gurame. Tercatat ada 6 kelompok petani ikan di desa Pasie Pinang, yang setiap kelompok terdiri atas 4 atau 5 anggota. Desa Pasie Pinang memiliki tingkat produksi budidaya ikan air tawar cukup besar di wilayah Meureubo, dengan hasil produksi rata-rata 20,68 ton/tahun.

Hasil Focus Group Discussion (FGD) dengan kelompok petani ikan diperoleh informasi bahwa ada masalah besar yang dialami oleh petani ikan yaitu serangan/infeksi penyakit. Persoalan tersebut sangat berpengaruh terhadap produksi ikan budidaya dan sangat merugikan petani. Penyakit ikan yang tiba-tiba menyerang menyebabkan tingkat kelangsungan hidup ikan saat pembenihan dan pembesaran ikan rendah, dan juga kadang-kadang ikan mati semua sehingga gagal panen yang berujung pada kerugian. Petani mengalami masalah dalam penangganan ikan yang terinfeksi penyakit, karena petani kurang memahami cara menghambat penularan penyakit dan pengobati ikan yang terinfeksi.

Permasalahan. Pendapatan kelompok mitra mengalami penurunan dan merugi, karena ikan yang berhasil panen sedikit. Sedikitnya hasil panen disebabkan oleh serangan/infeksi penyakit. Rendahnya pengetahuan petani tentang manajemen kesehatan ikan menyebabkan pengendalian penyakit tidak dapat di atasi. Pada dasarnya, timbulnya penyakit disebabkan oleh lingkungan, pathogen dan inang. Tiga penyebab tersebut dapat dikontrol dan diatasi dengan manajemen kesehatan yang benar sesuai dengan SOP. Berdasarkan pengamatan, dugaan awal timbulnya penyakit disebabkan oleh: mitra tidak melakukan karantina induk atau benih, padat tebar yang tinggi tanpa didukung manajemen kualitas air yang baik, dan pakan yang diberikan berlebihan. Apabila ikan terinfeksi penyakit, petani mengobati ikan sakit dengan obat kimia dan terus menerus sehingga mikroorganisme (bakteri) menjadi resisten.

\section{METODE PELAKSANAAN}

Program Kemitraan Masyarakat Stimulus (PKMS) dilaksanakan pada bulan Juni s/d Oktober 2020 di Desa Pasie Pinang Kecamatan Meureubo Kabupaten Aceh Barat Provinsi Aceh. Metode pelaksanaan dilakukan dengan beberapa pendekatan, yaitu sosialisasi dan pendampingan kelompok petani ikan.

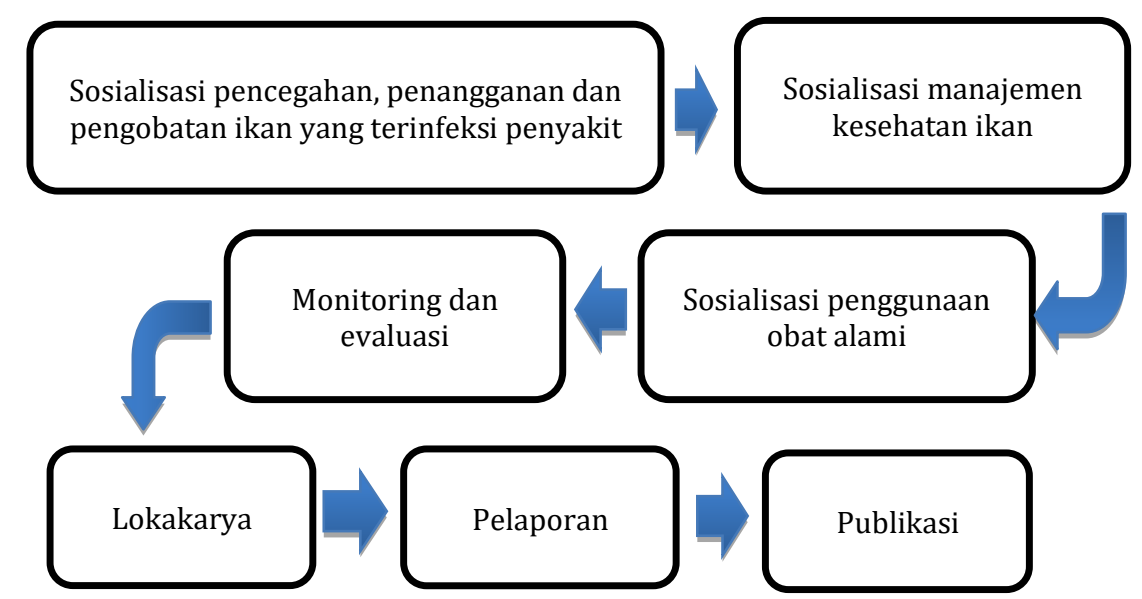

Gambar 1. Diagram alir susunan program 


\section{HASIL DAN PEMBAHASAN}

Hasil kegiatan pengabdian diperoleh bahwa petani ikan Desa Pasie Pinang Kecamatan Meureubo Kabupaten Aceh Barat yang aktif sebanyak 8 kelompok dari 10 kelompok yang ada. Petani mengalami masalah karena banyak ikan mati saat pemeliharaan (gambar 2). Diketahui ikan yang mati sebabkan oleh kolam kotor, kualitas air yang kurang bagus dan munculnya pathogen. Pathogen yang menyerang merupakan dari kelompok fungi yaitu saprolegnia. Fungi ini muncul akibat kualitas air yang buruk. Pada dasarnya penyakit muncul akibat interaksi ketiga faktor yaitu lingkungan, pathogen dan ikan. Untuk mengatasi fungi saprolegnia dilakukan dengan cara pembersihan kolam/pergantian air dan dilakukan pengobatan pada ikan yang terinfeksi dengan menggunakan obat herbal yaitu garam dan daun sirih.
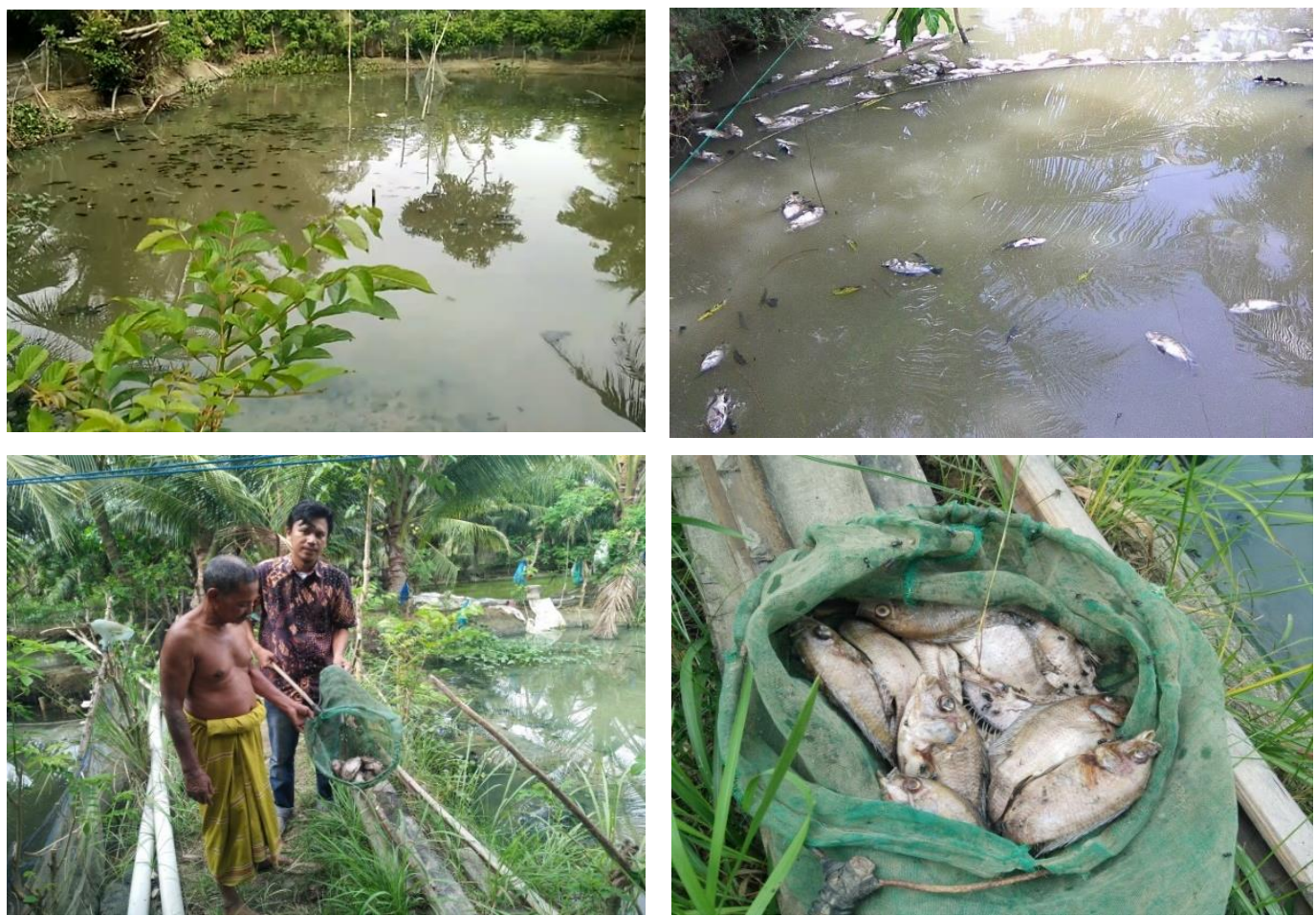

Gambar 2. Kualitas kolam dan air yang kurang bagus (kotor), dan ikan yang mati

Petani ikan mendapatkan materi tentang manajemen kesehatan ikan dan penggunaan obat herbal. Sosialisasi dilakukan dengan cara terjun langsung ke lokasi kolam petani ikan oleh tim pengusul. Tim pengusul melakukan diskusi tentang permasalahan penyakit dan cara pencengahannya.
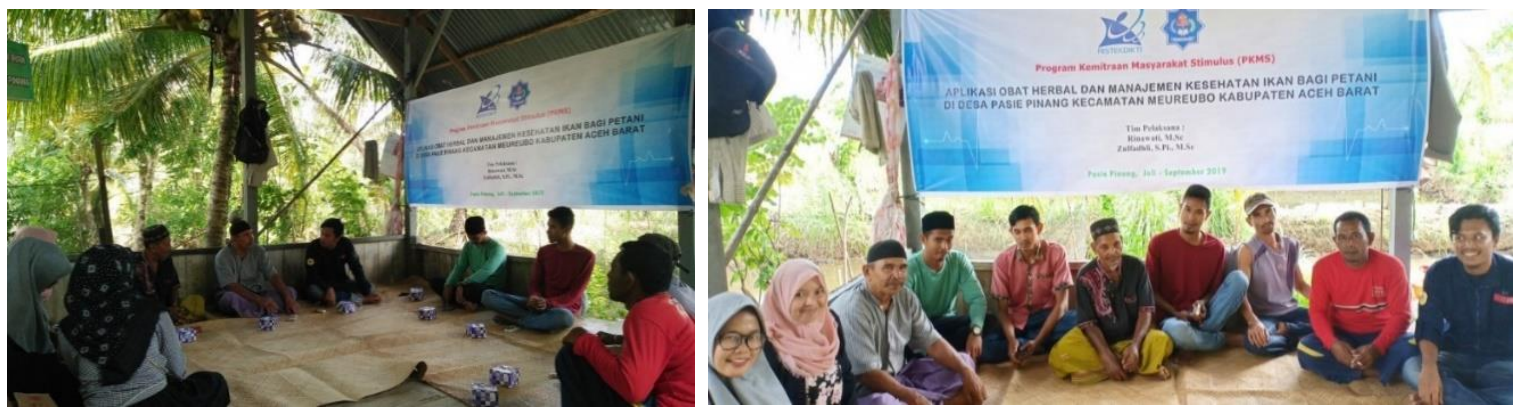

Gambar 3. Sosialisasi Manajemen kesehatan ikan dan penggunaan obat herbal 
Petani ikan sangat aktif ketika tim pengusul datang ke lokasi kolam untuk memberikan informasi tentang penyakit ikan. Petani mendapatkan pengetahuan dan pemahaman tentang penyakit ikan. Materi Sosialisasi yang diberikan yaitu:

A. Langkah-langkah yang dilakukan dalam pencegahan penyakit ikan, yaitu:

$>$ Tempat budidaya ikan sebelum digunakan terlebih dahulu di bersihkan, disucihamakan dan dikeringkan.

$>$ Peralatan secara rutin didensifektan untuk mencegah kontaminasi pathogen.

$>$ Kontrol ikan dan lingkungan budidaya, seperti jumlah kepadatan, kualitas air, dan penangganan yang baik.

> Benih atau induk ikan yang baru didatangkan dari luar harus di karantina terlebih dahulu.

> Meningkatkan sistem imun ikan dengan vaksin untuk kekebalan agar tidak terinfeksi

$>$ Penerapan Biosecurity dalam kegiatan budidaya.

B. Langkah-langkah yang dilakukan dalam penanganan dan pengobatan ikan :

> Ikan yang diduga terinfeksi penyakit harus segera dipisahkan dan dipindahkan ke tempat karantina atau tempat khusus untuk perawatan.

$>$ Melakukan diagnosa dengan pengamatan prilaku ikan dan pengamatan mikroskopik.

$>$ Hasil diagnosa akan memberikan informasi jenis penyakit dan segera diberikan obat. Pemberian obat dapat dilakukan dengan cara penyemprotan, perendaman, penyuntikan atau pemberian obat melalui pakan.

$>$ Kriteria obat yang baik adalah: tidak dilarang, memiliki takaran, tidak memiliki efek samping bagi konsumen dan lingkungan.

Hasil analisis Pre-Test dan Post-Test pada akhir dilakukan untuk mengetahui keberhasilan transfer pengetahuan kepada mitra (petani ikan). Hasil tes disajikan pada grafik dibawah ini :

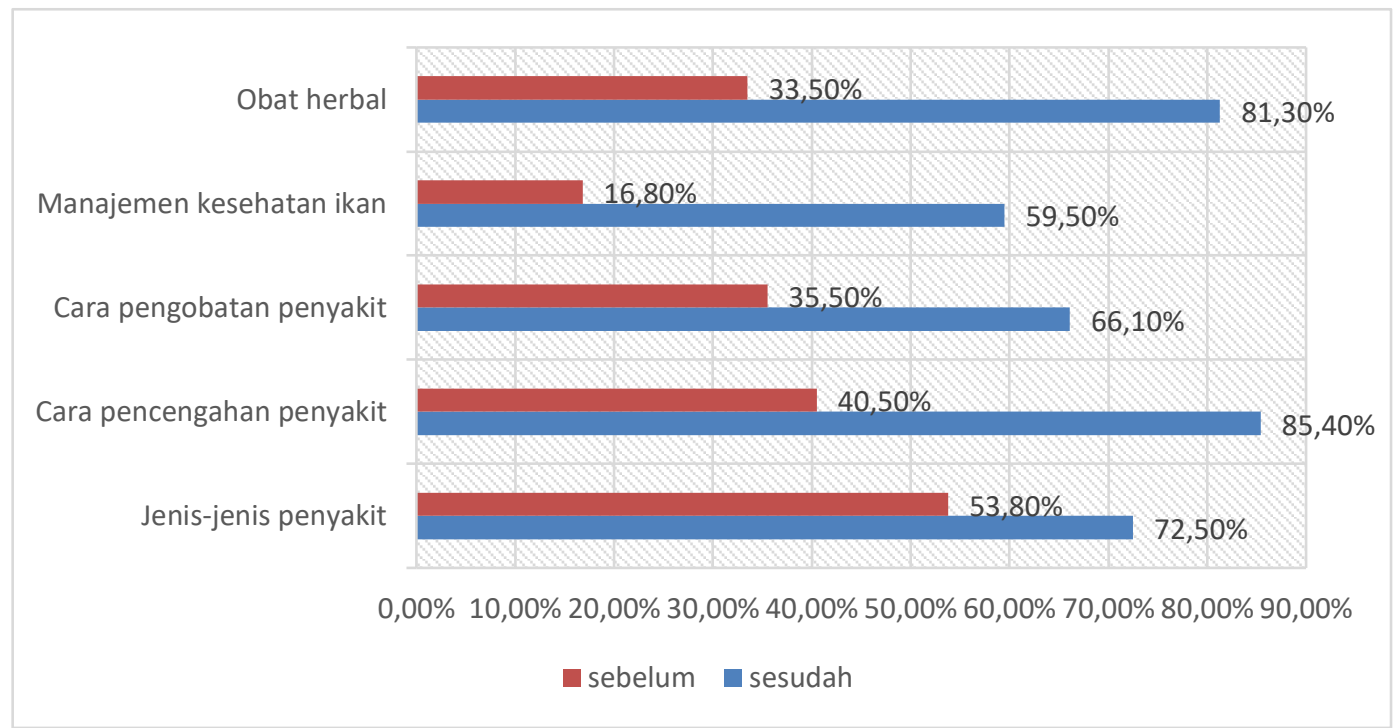

Gambar 4. Peningkatan pengetahuan petani ikan sebelum dan sesudah sosialisasi 
Berdasarkan gambar diatas (gambar 3), terjadi peningkatan pengetahuan disetiap indikator parameter yang di evaluasi. Pada parameter pertama obat herbal, petani sudah mengenal bahan herbal dan manfaatnya seperti daun sirih, kunyit, daun ketapang dan bawang putih. Namun petani belum tahu cara penggunaannya. Parameter kedua yaitu manajemen kesehatan ikan, petani masih sangat sedikit pemahaman tentang akibat munculnya penyakit dan cara mengelola ikan agar tidak terserang penyakit. Peningkatan pengetahuan pada parameter kedua sangat signifikan dari $16,8 \%$ (sebelum) meningkat menjadi $59,5 \%$ (sesudah). Selanjutnya parameter ke 3,4 dan ke 5 juga mengalami peningkatan pengetahuan, parameter ke 3 dari 35,5\% $66,1 \%$, parameter ke 4 dari 40,5\% - 85,4\%, dan parameter ke 5 dari 53,8\% - 72,5\%.

\section{KESIMPULAN}

Petani ikan mendapatkan peningkatan pengetahuan tentang manajemen kesehatan ikan dan penggunaan obat herbal melalui Program Kemitraan Masyarakat Stimulus (PKMS) Kemenristek Dikti.

\section{UCAPAN TERIMA KASIH}

Kementrian Riset Teknologi dan Pendidikan Tinggi yang telah memberikan pendanaan melalui Hibah Pengabdian Kepada Masyarakat Stimulus (PKMS) pendanaan 2019, dan LPPM-PM Universitas Teuku Umar yang telah membantu dalam hal administrasi.

\section{DAFTAR PUSTAKA}

DKP Aceh Barat. 2017. Dinas Kelautan dan Perikanan Kabupaten Aceh Barat. Meulaboh.

Noga EJ. 2000. Fish disease diagnosis and treatment. lowa State Press. A Blackwell Publishing Company.

Zulfadhli, Z., Andila, I., Diana, F., \& Rinawati, R. (2017). Pengaruh Ekstrak Batang Serai (Cymbopogon citratus) Terhadap Pertumbuhan Bakteri Edwardsiella tarda Secara In Vitro. Jurnal Akuakultura Universitas Teuku Umar, 1(1).

Zulfadhli, Z., \& Rinawati, R. (2018). Potensi Selada Laut Ulva lactuca Sebagai Antifungi Dalam Pengendalian Infeksi Saprolegnia Dan Achlya Pada Budidaya Ikan Kerling (Tor sp). Jurnal Perikanan Tropis, 5(2), 183-188. 